\title{
The Impact of Mine Effluents on the Water Quality and Macrophyte Plant Communities in the Kifubwa Stream, Solwezi, Zambia
}

\author{
Ketty M. Namwanja, Stanford M. Siachoono*, Arthur M. Yambayamba, Lackson Chama \\ School of Natural Resources, Copperbelt University, Kitwe, Zambia \\ Email: *stanford.siachoono@cbu.ac.zm
}

How to cite this paper: Namwanja, K.M., Siachoono, S.M., Yambayamba, A.M. and Chama, L. (2018) The Impact of Mine Effluents on the Water Quality and Macrophyte Plant Communities in the Kifubwa Stream, Solwezi, Zambia. Natural Resources, 9, 198-211.

https://doi.org/10.4236/nr.2018.95013

Received: December 1, 2017

Accepted: May 28, 2018

Published: May 31, 2018

Copyright $(9) 2018$ by authors and Scientific Research Publishing Inc. This work is licensed under the Creative Commons Attribution International License (CC BY 4.0).

http://creativecommons.org/licenses/by/4.0/

(c) (i) Open Access

\begin{abstract}
A study to assess the impact of mine effluents on water quality and macrophyte plant communities in the Kifubwa stream in Solwezi, Zambia was carried out in December 2015. The macrophytes species and water samples were collected from ten (10) selected sampling sites along the river. The initial sampling site was set at the point of pollution (effluents) entrance into the river. The other 9 sampling units of $30 \mathrm{~m} \times 30 \mathrm{~m}$ were spaced at a uniform interval of $150 \mathrm{~m}$ throughout the $1.5 \mathrm{~km}$ section of the river sampled. Macrophytes collected at each sampling site were identified on site to family level using the Zambian Macrophytes Trophic Ranking (ZMTR) protocol developed under the Southern African River Assessment (SAFRASS). The abundance of macrophyte plant communities showed that family Polygonaceae had (27.5\%), Cyperaceae, (23.5\%), Amaranthaceae (17.6\%), Hydrocharitaceae (17.6\%) and Osmundaceae (13.8\%) respectively. The Shannon-Weiner's diversity index $(H)$ was used to calculate the macrophyte diversity and the value used in a correlation analysis with potential of hydrogen $(\mathrm{pH})$ and other water quality variable under investigation. The water samples were taken to the laboratory for analysis of water variables, namely, $\mathrm{pH}$, Total Dissolved Solids (TDS), nitrates, phosphates, copper and zinc levels for each site. The $\mathrm{pH}$ was significantly $(p<0.05)$ related to TDS, phosphates nitrates and copper $\mathrm{pH}$ was not significantly $(p>0.05)$ related to $H$ and zinc. Calculated means for $\mathrm{pH}$ and TDS showed that they were within both the Zambian Drinking Water Standards (ZDWS) and the World Health Organization (WHO) guidelines. Phosphates, nitrates and zinc were all below both water standards. Only copper levels were above both water standards. The mine effluent that is being discharged in the Kifubwa stream does have an impact on the water quality parameters, especially that of copper. This requires regular monitoring of the stream effluents by the authorities that give the permission for the discharge.
\end{abstract}




\section{Keywords}

Macrophytes, Mining Effluent, Water Quality, Water Parameters

\section{Introduction}

Streams and rivers are a major source of fresh water in Zambia; however industries such as mining generate effluents that have the potential to pollute such water bodies that are within their environment [1] [2] [3]. Pollutant concentrations when discharged in a stream should however be with the approved standards that are considered safe for aquatic life and human health [4] [5] [6]. In this respect, the Zambia Environmental Management Act [7] gives guidelines on the threshold of the effluent discharge levels from industrial and sewerage waste.

Mine effluents and industrial waste in general can alter the physical, chemical, and biological nature of the receiving water body such as streams [8]. In return, this affects their potential usage for domestic, industrial, recreational, and agricultural purposes. Conventional pollutants (e.g. oil and grease), toxic pollutants (e.g. heavy metals, volatile organic compounds) and other non-conventional pollutants (e.g. nitrates, phosphates and ammonium compounds) are often found in industrial waste waters, which has been of particular interest in recent times.

Heavy metals and complex organic compounds are the most important contaminants in waste water effluents that are present in abundance and are toxic [9]. For example, acid mine drainage, a condition created by effluents when disposed into stream and river waters, impacts on the quality of receiving waters. Tetra Tech NUS Inc. [10] reported the impact of acid mine drainage on Ely Brook's river water quality as was determined by physical and biological factors such as metals and biota, respectively. McMenemy [11] reported the non-survival of aquatic organisms, which was cropped for one year, in Ely Brook River due to extremely poor survival and growth conditions. The effluents thus can change the ecosystems in streams and rivers if they do not meet stream and river water quality requirements. Life of species in streams and rivers and that of man can be affected. Aquatic species growth can be retarded and can even die altogether [12].

In Zambia, regulatory frameworks have been developed in the last two decades aimed at controlling and enforcing pollution standards [7]. Similarly, the National Water and Sanitation Council (NAWSCO) under the Water Act [13] provide guidelines for safe drinking water in conformity with global standards under the World Health Organization [14] to all water utility companies.

This study was conducted to assess the impact of the mining effluents being discharged in the Kifubwa stream in Solwezi in North Western Zambia on the water quality and its possible effects on macrophytes growing in the stream (Figure 1). The water quality parameters included the potential of hydrogen 


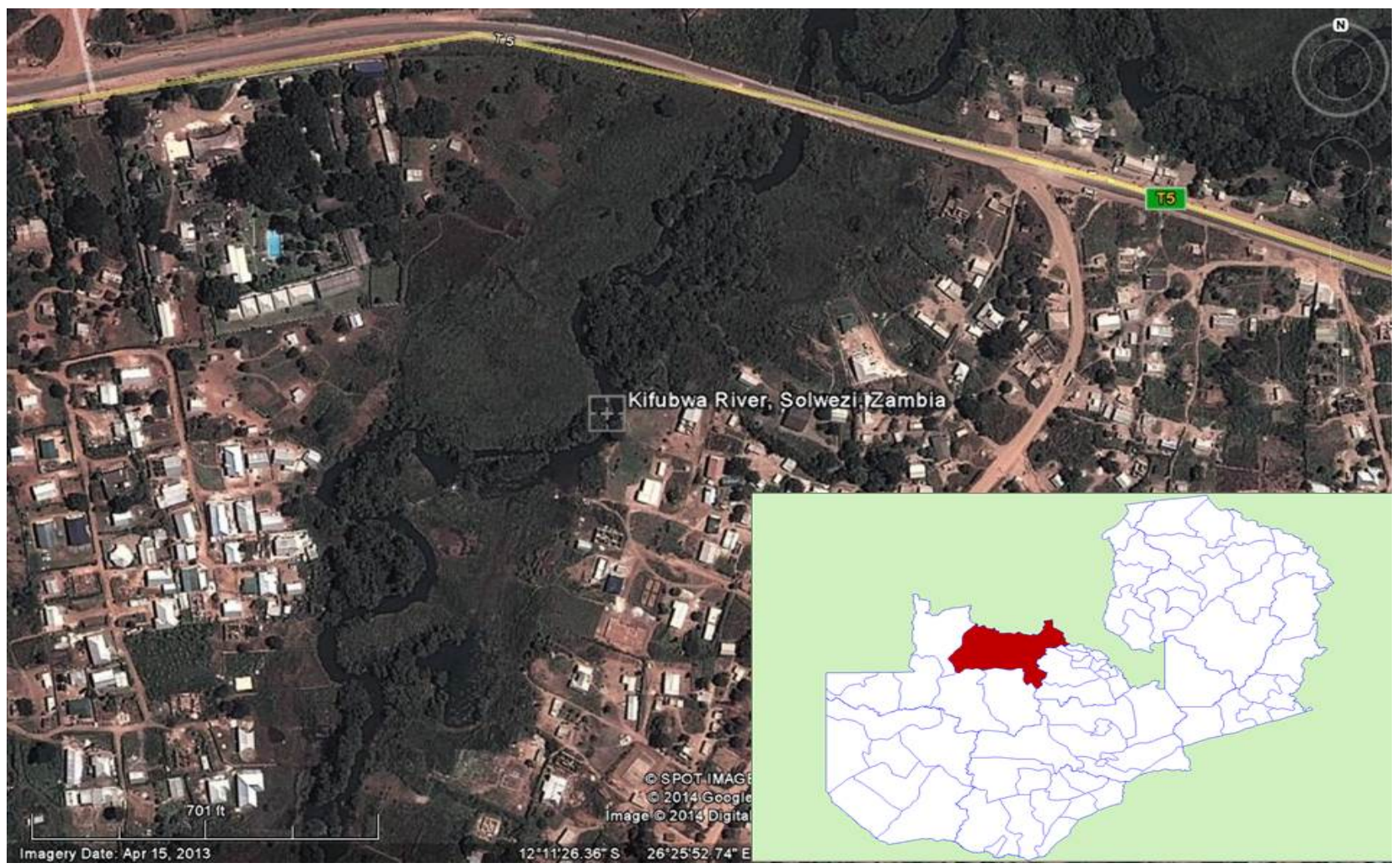

Figure 1. Solwezi district showing the study area between houses; Source: Google Earth, 2014.

$(\mathrm{pH})$, Total Dissolved Solids (TDS), Nitrates $\left(-\mathrm{NO}_{3}\right)$ Phosphates $\left(\mathrm{PO}_{4}\right)$ while the heavy metals assessed were copper $(\mathrm{Cu})$ and Zinc $(\mathrm{Zn})$. Macrophyte plant species were used for correlation tests with other variables in order to understand the water quality of the stream.

The Kifubwa stream runs through a section of town settlements and carries with it mining effluents that are discharged from the Kansanshi mine. The mine produces copper and gold from open pit mining.

\section{Methodology}

\subsection{Study Site}

This study was carried out in Kifubwa River which is located $5 \mathrm{~km}$ East of Solwezi town in the North-Western Province. The source of the river is the Kifubwa Hill, located at an elevation of $1569 \mathrm{~m}$ above sea level whereas the Kifubwa River lies at an elevation of $1213 \mathrm{~m}$ and $1569 \mathrm{~m}$, and the elevation increases towards the north side of Solwezi which borders Zambia and the Democratic Republic of Congo. The river starts as a trickle from the Kifubwa Hill and with little slope to speed up the flow, it meanders south-eastwards sluggishly and within $45 \mathrm{~km}$ has the character of a mature river. The river contains different types of fish species, invertebrates, macrophytes and other aquatic animals, and experiences a tropical savannah climate. The annual precipitation can vary by significant amount but is generally within the range of $1000 \mathrm{~mm}$ to $1500 \mathrm{~mm}$ 
due to the location of Solwezi which is near the Congo basin, the average depth is $3.7 \mathrm{~m}$ [15].

\subsection{Experimental Design}

A reconnaissance survey of the stream was carried out; and then systematic sampling was used to establish 10 selected stations (sampling sites labelled S1, S2, S3, S4, S5, S6, S7, S8, S9 and S10) along the river. The initial sampling unit or station was set at the point of pollution (effluents) entrance into the river. The other 9 sampling units of $30 \mathrm{~m} \times 30 \mathrm{~m}$ were spaced at a uniform interval of 150 $\mathrm{m}$ throughout the $1.5 \mathrm{~km}$ section of the river sampled.

\subsection{Sampling}

At each sampling unit or station, the water samples and the species of macrophytes present were collected. The water samples were collected using plastic bottles and taken to the lab for analysis of $\mathrm{pH}$, Total Dissolved Solids, nitrates, phosphates and metals such as copper and zinc. While the species of macrophytes taken at each station were counted and identified on site using a ZMTR (Zambian Macrophytes Trophic Ranking) developed under Southern African River Assessment Scheme (SAFRASS) [16] [17] and those that could not be identified on site were put on newspapers placed on two pieces of carton boxes and then tied and carried for identification.

\subsection{Data Analysis}

The $\mathrm{pH}$ was measured using the $\mathrm{HACH}$ spectrometer equipment. Nitrates and phosphates were measured using the UV-V Spectrometer according to APHA [18] whereas the concentrations of $\mathrm{Cu}$ and $\mathrm{Zn}$ were measured using an Inductively Coupled Plasma-Optical Emission Spectrometer as recommended by APHA [18].

Macrophytes species diversity, i.e. relative abundance, on each sampling site was determined by the Shannon-Weiner's diversity index, $H$, [19] given by:

$$
H=-\sum_{i=1}^{n}\left(p_{i} * \ln \left(p_{i}\right)\right)
$$

where $p_{i}$ is the proportional abundance of the ith species and $n$ is the total number of species encountered at given sampling site.

Correlation analysis was conducted to determine whether there was linear relationship (and the strength) between $\mathrm{pH}$ and the other variables (i.e. TDS, phosphates, nitrates, copper and zinc and $H$ ) as well as between TDS and phosphates, nitrates, copper, zinc and $H$. Before conducting the analysis, the data sets were subjected to normality checks and tests, using both graphical and numerical methods. The Shapiro-Wilk test was conducted to determine whether the data set for each variable was normally distributed. In addition to the normality test, boxplots were also used to give a visual impression of the distribution of the 
data sets and to crosscheck the results of the normality test. All the analysis was done using IBM SPSS version 20 and all tests were conducted at the $5 \%$ level of significance. Figure 2 was generated in RStudio version 1.0.143 [20].

\section{Results}

A total number of seven (7) macrophytes species, identified to a family level using the SAFRASS protocol, [16] were sampled across sampling sites and identified; the family Polygonaceae had the highest number of species, seconded by $\mathrm{Cy}$ peraceae whereas Amaranthaceae and Hydrocharitaceae had the third highest number of species and Osmundaceae had the least abundance of species (Table 1).

Test for normality based on Shapiro-Wilk was non-significant $(p>0.05)$ for pH, TDS, Phosphates, Zinc and $H$ (Table 2). Tests were supported with boxplots which did not indicate obvious departures from normality (Figure 2). The Shapiro-Wilk test was significant $(p>0.05)$ for nitrates and copper data sets (Table 2). Boxplots also revealed obvious departures from normality for these two data sets (Figure 2). For this reason, standard errors and 95\% confidence intervals for the two variables were determined based on bootstrapping methods [21]. The summary statistics for the variables considered in the study were as shown in Table 3.

Table 1. Types of macrophytes, and their abundance in percentages, identified/collected in the Kifubwa river.

\begin{tabular}{cccc}
\hline Family & Species & $\begin{array}{c}\text { Total number } \\
\text { of counts }\end{array}$ & $\begin{array}{c}\text { Abundance in } \\
\text { percentage (\%) }\end{array}$ \\
\hline Amaranthaceae & Alternanthera sessils & 9 & 17.6 \\
Cyperaceae & Eleocharis dulcis & 5 & 9.8 \\
Hydrocharitacea & Schoenoplectus corymbosus & 7 & 13.7 \\
Osmundaceae & Vallisneria spiralis & 9 & 17.6 \\
Polygonaceae & Osmunda regalis & 7 & 13.7 \\
& Persicaria decipiens & 6 & 11.8 \\
& Persicaria attenuata & 8 & 15.7 \\
\hline
\end{tabular}

Table 2. Tests for Normality based on Shapiro-Wilk test.

\begin{tabular}{cccc}
\hline \multirow{2}{*}{ Variable } & \multicolumn{3}{c}{ Shapiro-Wilk Test } \\
\cline { 2 - 4 } & Statistic & Sample size & p-Value \\
\hline pH of water samples & 0.899 & 10 & 0.215 \\
Total Dissolved Solids & 0.893 & 10 & 0.184 \\
Nitrates & 0.745 & 10 & 0.003 \\
Phosphates & 0.930 & 10 & 0.446 \\
Copper & 0.680 & 10 & 0.001 \\
Zinc & 0.903 & 10 & 0.239 \\
Shannon-Weiner's Diversity Index & 0.915 & 10 & 0.313 \\
\hline
\end{tabular}


Table 3. Summary statistics for the water samples.

\begin{tabular}{cccccccc}
\hline \multirow{2}{*}{ Statistic } & \multicolumn{7}{c}{ Variable } \\
\cline { 2 - 8 } & $\mathrm{pH}$ & TDS & $\boldsymbol{H}$ & Nitrates & Phosphates & Copper & Zinc \\
\hline \multirow{2}{*}{ Mean \pm} & $7.270 \pm$ & $467.400 \pm$ & $1.04 \pm$ & $0.410 \pm$ & $2.870 \pm$ & $2.734 \pm$ & $0.177 \pm$ \\
$S E$ & 0.206 & 109.060 & 0.10 & $0.062^{*}$ & 0.251 & $0.331^{*}$ & 0.008 \\
& & & & & & & \\
$95 \% C I$ & {$[6.805$,} & {$[220.690$,} & {$[0.82$,} & {$[0.040$,} & {$[2.303$,} & {$[2.126$,} & {$[0.159$,} \\
& $7.735]$ & $714.110]$ & $1.26]$ & $0.260]^{*}$ & $3.437]$ & $3.434]^{*}$ & $0.195]$ \\
\hline
\end{tabular}

$S E=$ standard error of the mean; $C I=$ confidence interval. ${ }^{\star} S E$ and $95 \% C I$ both based on 1000 bootstrap samples (except for nitrates which had 999 samples); the $95 \%$ CI for nitrates is based on Bias corrected and accelerated confidence interval (BCa).

\subsection{Comparison of Water Sample Results with ZDWS and WHO Standards}

Table 4 shows how the mean values from the water samples compare with ZDWS and WHO standards. Based on calculated means, $\mathrm{pH}$ and TDS were both within ZDWS and WHO guidelines while phosphates, nitrates and zinc were all below both standards. Copper was the only variable above both standards (Table 4).

Table 4. Comparison of results obtained with ZDWS and WHO standards.

\begin{tabular}{cccc}
\hline Variable & Mean obtained & ZDWS Standards & WHO Standards \\
\hline $\mathrm{pH}$ & 7.270 & $6.5-8.0$ & $6.5-9.5$ \\
TDS & 467.400 & 500 & 600 \\
Phosphates & 2.870 & 5 & 5 \\
Nitrates & 0.410 & 10 & 50 \\
Copper & 2.734 & 1 & 2 \\
Zinc & 0.177 & 5 & 3 \\
\hline
\end{tabular}

\subsection{Correlation Analysis}

The results for the correlation analysis were as shown in Table 5 .

The correlation coefficients under nitrates and copper were all based on Kendall's tau, $\tau$, because of the non-normality of the data sets and also the number of tied ranks [21] for nitrates.

$\mathrm{pH}$ was significantly related to TSD $(p=0.002)$, phosphates $(p=0.003)$, nitrates $(p=0.033)$ and copper $(p=0.044)$. Since all the three significant correlation coefficients (for $\mathrm{pH}$ and the other variables) were negative, it implies that as $\mathrm{pH}$ of the water increased (along the stretch of the stream) the amounts of TDS, phosphates, nitrates and copper decreased. There was no significant relationship between $\mathrm{pH}$ and zinc $(p=0.826)$ and $\mathrm{pH}$ and $H(p=0.063)$. TSD was significantly related to phosphates $(p=0.001)$, nitrates $(p=0.004)$ and copper $(p=$ 0.016). The significant correlation coefficients between TDS and the other variables, except $\mathrm{pH}$, were all positive indicating that as the amount of TDS increased, the amount of phosphates, nitrates and copper also increased. There 
was no significant relationship between TDS and zinc $(p=0.637)$ and TDS and $H(p=0.085)$, although the BCa bootstrap 95\% confidence interval showed otherwise. Graphical display of scatter plots showed somewhat moderate negative linear relationship between $\mathrm{pH}$ and $H$ and also a moderate positive linear relationship between TDS and $H$ (Figure 2). This was also reflected in the values obtained for $r$. Thus, even though the results were not statistically significant, a linear relationship between $\mathrm{pH}$ and $H$ and also TDS and $H$ could be plausible.

Table 5. Correlation matrix for $\mathrm{pH}$ and TDS versus the other variables.

\begin{tabular}{cccccccc}
\hline & pH & TDS & $H$ & Nitrates & Phosphates & Copper & Zinc \\
\hline \multirow{3}{*}{ pH } & \multirow{2}{*}{1} & $-0.839^{* *}$ & $-0.606^{\text {ns }}$ & $-0.569^{*}$ & $-0.833^{* *}$ & $-0.719^{* *}$ & $-0.080^{\mathrm{ns}}$ \\
& & {$[-0.998$,} & {$[-0.953$,} & {$[-0.861$,} & {$[-0.973$,} & {$[-0.950$,} & {$[-0.879$,} \\
& & $-0.366]$ & $0.070]$ & $-0.098]$ & $-0.547]$ & $-0.410]$ & $0.500]$ \\
\multirow{2}{*}{ TDS } & & & $0.571^{\mathrm{ns}}$ & $0.767^{* *}$ & $0.869^{* *}$ & $0.600^{*}$ & $0.171^{\mathrm{ns}}$ \\
& & \multirow{2}{*}{1} & {$[0.117$,} & {$[0.375$,} & {$[0.509$,} & {$[0.000$,} & {$[-0.836$,} \\
& & & $0.838]$ & $0.973]$ & $0.996]$ & $1.000]$ & $0.956]$ \\
\hline
\end{tabular}

ns $=$ not significant $(p>0.05),{ }^{*} p<0.05,{ }^{* *} p<0.01,{ }^{* *} p<0.001$. BCa bootstrap $95 \%$ confidence intervals (CIs) reported in brackets.

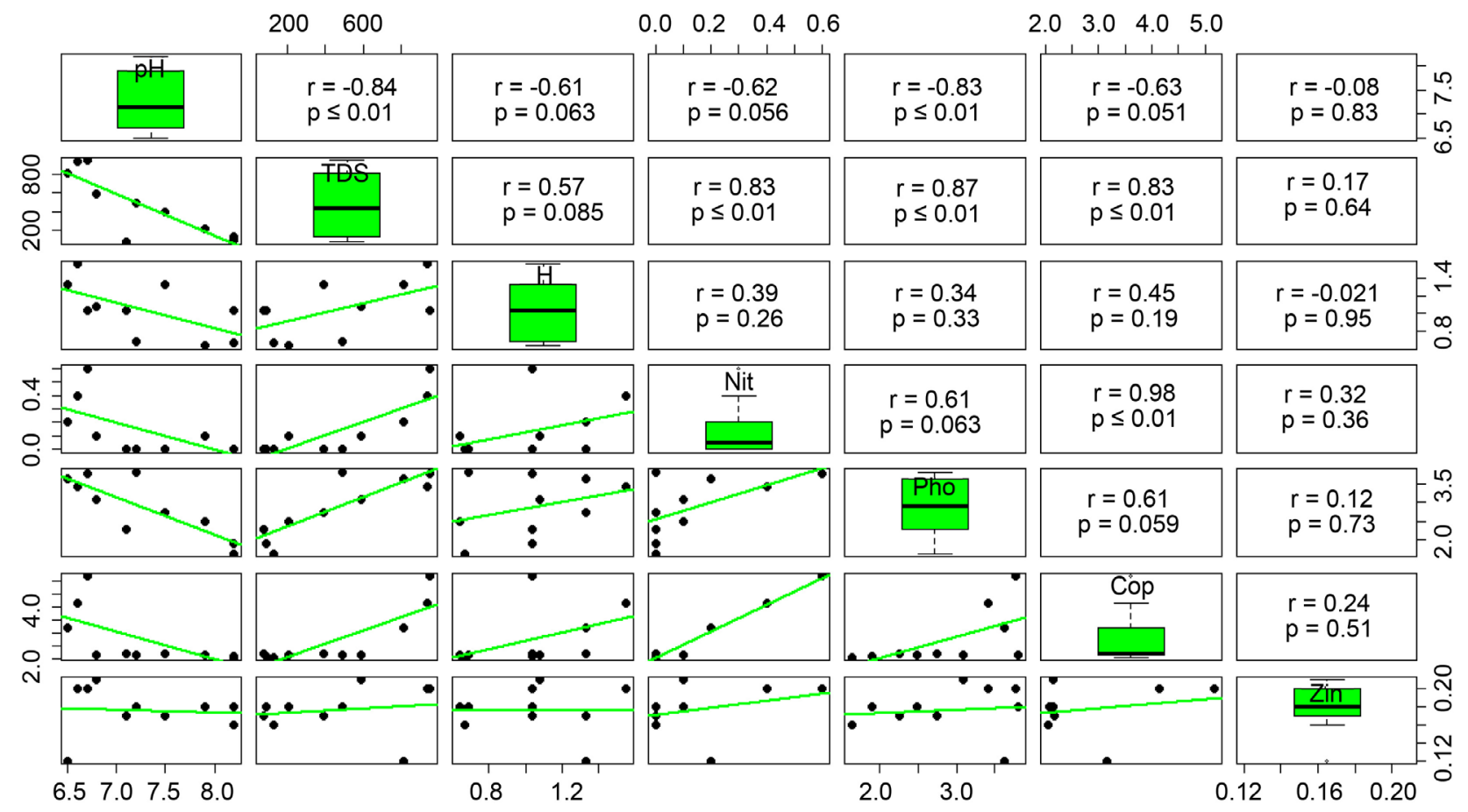

Figure 2. Scatterplot matrix for $\mathrm{pH}$, TDS, $H$, Nitrates, Phosphates, Copper and Zinc. The green line (straight) is the robust-regression line for each pair; the upper panel consists of correlation coefficients and their corresponding $\mathrm{p}$-values. $\mathrm{pH}=\mathrm{po}-$ tential of hydrogen, TDS = Total Dissolved Solids, H = Shannon-Weiner's diversity index, Nit = Nitrates, Pho = Phosphates, Cop = Copper and Zin = Zinc.

\section{Discussion}

From the results, the different species of aquatic macrophytes found during the study period and their abundance using the number of species belonging to 
various families indicates that the species found are common aquatic macrophytes found around the wetlands of Southern Africa [22]. A total number of 5 families (Amaranthaceae, Cyperaceae, Hydrocharitaceae, Osmundaceae and Polygonaceae were identified in the study area with Polygonaceae having the highest percentage abundance of $27.5 \%$, Cyperaceae was second with percentage abundance of $23.5 \%$ whereas Amaranthaceae and Hydrocharitaceae were third with the percentage abundance of $17.6 \%$ and Osmundaceae was the least with the percentage abundance of $13.7 \%$ (Table 1 ).

\subsection{The Effect of $\mathrm{pH}$ on Water Quality and Macrophytes Abundance}

The mean $\mathrm{pH}$ was within WHO [14] and ZDWS permissible limits (6.5 - 9.5). However, the increase in $\mathrm{pH}$ at some sampling sites could be due to the self-purification of the river and chemicals from mine effluents that did not move far in terms of dilution. Furthermore, there was a notable decrease in $\mathrm{pH}$ in the first five (5) stations which could be as a result of macrophytes and mine effluents from the Kansanshi mines which enter the river through the Kansanshi stream. The $\mathrm{pH}$ can be decreased by the carbon dioxide released by the bacteria breaking down the organic wastes [23]. Carbon dioxide dissolves in water to form carbonic acid. Also extensive growth of free floating aquatic macrophytes can cause a reduction in $\mathrm{pH}$ [24]. As reported in Salequzzaman [25] $\mathrm{pH}$ changes can tip the ecological balance of aquatic system and excessive acidity can result in the release of hydrogen sulphide. However, the results indicate that there was no correlation between water $\mathrm{pH}$ and macrophytes abundance. The results indicate that the water $\mathrm{pH}$ was not a limiting factor on the growth and abundance of macrophytes in the Kifubwa River. According to El-Gendy [26], optimal water $\mathrm{pH}$ for growth of water hyacinth is neutral but can tolerate $\mathrm{pH}$ values from 4 to 10 .

\subsection{The Effect of TDS on Water Quality and Macrophytes Abundance}

The mean TDS was less than WHO and ZDWS. However, the TDS values of the first three (3) sites exceeded both the WHO [14] guidelines and the ZDWS. The mean salinity of world's rivers is approximately $120 \mathrm{mg} / \mathrm{L}$ and the major an ion found in natural waters is bicarbonate [27]. The increase in the concentration of TDS at the three (3) sites may be due to mine effluents from the Kansanshi stream which contain both organic and inorganic ions. According to Nadia [28] discharge of wastewater with a high TDS level would have adverse impact on aquatic life, render the receiving water unfit for drinking and domestic purposes, reduce crop yield if used for irrigation, and exacerbate corrosion in water networks. According to Thorne and Peterson [29] TDS levels above $700 \mathrm{mg} / \mathrm{L}$ are unsuitable for irrigation of some crop species. Hallock and Hallock [30] reported substantial changes in marsh communities. When TDS increased from 270 to $1170 \mathrm{mg} / \mathrm{L}$, both coontail (ceratophyllus dermersum) and cattails (Typha sp.) 
were nearly eliminated. Furthermore, the notable decrease of TDS levels in the last seven (7) stations is due to the macrophytes capacity to take some organic and inorganic ions. However, the results indicated a negative correlation between TDS and macrophytes abundance along the Kifubwa River at the time of sampling. The results suggest that as the concentration of TDS increases, even the absorption capacity of macrophytes increases. Ebrahim et al. [31] found that Vetiver root can remove TDS in water about $55.95 \%$ by absorption.

\subsection{The Effect of Nitrates on Water Quality and Macrophytes Abundance}

The nitrate levels ranged from less than 0.01 to $0.6 \mathrm{mg} / \mathrm{l}$. The water had levels of nitrates below WHO [14] guidelines and Zambian Drinking Water standards. The concentration of nitrates in the river may be as a result of agricultural runoffs and animal feeds from nearby farms and decomposition of plants and animals. Nitrate contamination of aquifers is often linked to agricultural (chemical fertilizer, manure and animal feeds lots) and non-agricultural (waste-water and solid waste disposal) sources [32] [33]. The decrease in nitrate levels in six (6) stations is probably as a result of aquatic plants (macrophytes) capacity to take up nitrates. Mkandawire and Dudel [34] reported the reduction in nitrate due to plants ability to absorb different types of pollutants and accumulate them in their tissues. Nitrogen may cause aquatic biological productivity to increase, resulting in low dissolved oxygen and eutrophication of lakes, rivers, estuaries, and marine waters [35]. However, the results revealed that nitrate correlated negatively with macrophytes abundance. This shows that low levels of nitrate favoured macrophytes abundance. According to $\mathrm{Lu}$ [36] impressive removal rates of nitrates have been reported using aquatic plants especially when Water hyacinths were utilized in nutrients or metal rich wastewaters.

\subsection{The Effect of Phosphates on Water Quality and Macrophytes Abundance}

The mean phosphate levels were generally below the WHO guideline and ZDWS of limits $(5 \mathrm{mg} / \mathrm{L})$ at all sampling sites, however S1 was higher than $(\leq 0.05 \mathrm{mg} / \mathrm{l})$ for streams discharging into reservoirs, and both S1 and S3 were higher than $(\leq 0.025 \mathrm{mg} / \mathrm{l})$ for reservoirs recommended by the US Environmental Protection Agency [37]. The level of phosphates in the river is due to agricultural and industrial wastes. Fertilizers containing high levels of phosphates enter the river through runoffs and erosion. Phosphates enter waterways from human and animal waste, phosphate rich bedrock, wastes from laundry cleaning and industrial processes, and fertilizer runoff [38]. Phosphate may cause aquatic biological productivity to increase, resulting in low dissolved oxygen and eutrophication of lakes, rivers, estuaries, and marine waters [35]. The uniform trend of decrease in the levels of phosphates from S6 to S10 is as a result of aquatic plants (macrophytes) ability in absorbing nutrients. Mkandawire and Dudel [34] reported the reduction in phosphates due to plants ability to absorb different types of pollut- 
ants and accumulated in their tissues. However, the results indicate that phosphates correlated negatively with macrophytes abundance. The results show that as phosphate increases, even the absorption rate and abundance of macrophytes increases. Macrophytes are efficient accumulator of nutrients and heavy metals [39] [40]. According to Lu [36] impressive removal rates of phosphates have been reported using aquatic plants especially when Water hyacinths were utilized in nutrients or metal rich wastewaters.

\subsection{The Effect of Copper on Water Quality and Macrophytes Abundance}

Copper was above both the maximum permissible limits (MPL) for WHO [14] and ZDWS across sampling sites. The concentration of copper ranged from 2.04 $\mathrm{mg} / \mathrm{l}$ to $5.18 \mathrm{mg} / \mathrm{l}$. The high level of copper may be due to the mine effluents containing copper metal chips from metal fabricating operations involving $\mathrm{Cu}$ scrap. These copper levels exceeded the threshold level for irrigations $(0.1 \mathrm{mg} / \mathrm{L})$ and freshwater aquatic life $(0.02 \mathrm{mg} / \mathrm{L})$ [ 41$]$. The level of $0.02 \mathrm{mg} / \mathrm{L}$ copper is recommended as the threshold concentration to maintain freshwater aquatic life. Although copper toxicity in humans is rare, aquatic organisms are potentially at risk from $\mathrm{Cu}$ exposures [42]. Copper concentrations that exceed $20 \mathrm{mi}-$ crogram per gram $(\mu \mathrm{g} / \mathrm{g})$ can be toxic [43]. The low copper concentrations observed down the stream are attributed to the natural purification processes within the river and this is in agreement with the findings of Muwanga and Barifaijo [44]. However, the results showed a negative correlation between copper and macrophytes abundance during the sampling period (Table 5). The results indicate that as the copper concentration reduces, even the abundance of macrophytes reduces. According to Wei and Zheng-Hua [45] A. philoxeroides persists and growth within copper contaminated waters. Macrophytes can accumulate heavy metals 100,000 times greater than in the associated water [46].

\subsection{The Effect of Zinc on Water Quality and Macrophytes Abundance}

The zinc levels were below WHO [14] guidelines and Zambian Drinking Water standards. The concentration of zinc in the river may be attributed to mine effluents and agricultural runoffs. Zinc is essential micronutrient becoming toxic when present in excessive concentrations [47]. In soft water, zinc can be lethal to fish at concentrations ranging from $0.1 \mathrm{mg} / \mathrm{L}$ to $1.0 \mathrm{mg} / \mathrm{L}$. According to a report by Finlayson and Rectenwald [48] Zn concentrations of $1.4 \mathrm{mg} / \mathrm{L}$ were measured during fish kill in the Mokelume River in 1958. However, the results showed a negative correlation between zinc and macrophytes abundance. The results suggest that the zinc levels were therefore not a limiting factor to the abundance of macrophytes in Kifubwa River. According to Jain et al., [49] plants utilize zinc as a micronutrient for their growth. E. Crassipes removed $\mathrm{Zn}$ safely at all concentrations i.e. 5.0, 10.0, 15.0, and $20.0 \mathrm{mg} / \mathrm{L}$ [50]. 


\section{Conclusion}

This study was carried out on the Kifubwa River, with the main aim of determining the impact of mining effluents on water quality and macrophytes abundance. The results of the investigation showed that $\mathrm{pH}$ had no impact on water quality of the Kifubwa River, whereas the other water parameters (TDS, nitrates, phosphates, copper and zinc) had some impact on the water quality of the river. The concentrations of TDS, nitrates, phosphates, copper and zinc were higher at some sites than the Zambian drinking water standards (ZDWS) and WHO's recommended limits. On the other side, the water parameters of the Kifubwa River showed no impact on the abundance of macrophytes. The parameters and macrophytes were found to be negatively related and the nutrient levels were within the normal range for macrophytes growth. In addition, excess nutrients can lead to eutrophication and result in macrophyte bloom. Therefore, there is the need to monitor the water quality of parameters of this river at regular intervals to determine its nutrient level in relation to the assemblage and density of macrophytes in the river system.

\section{Acknowledgements}

The authors would like to thank the following individuals for their support while in the field: Mr. B. Lupali and Mr. B. Mupakile, Mr. and Mrs. Hamunjo, Ms. Fastina Nayondo Mwanja. The authors also thank the Copperbelt University for providing the working space in preparing this work.

\section{References}

[1] Cheung, K.C., Poon, B.H.T., Lan, C.Y. and Wong, M.H. (2003) Assessment of Metal and Nutrient Concentrations in River Water and Sediment Collected from the Cities in the Pearl River Delta, South China. Chemosphere, 52, 1431. https://doi.org/10.1016/S0045-6535(03)00479-X

[2] Gabriel, O., Rita, O., Clifford, A., Cynthia, O., Harrison, N. and Kennedy, O. (2006) Heavy Metal Pollution of Fish of Qua-Iboe River Estuary: Possible Implications for Neurotoxicity. International Journal of Toxicology, 3, 1559-3916.

[3] Peter, A.T. and Rodney, T.B. (2007) Pollution of a Tasmanian River by Mine Effluents 1, Chemical Evidence. Internationale Revue der gesamten Hydrobiologie und Hydrographie, 58, 873-883.

[4] Ethan, J.N., Richard, W.M. and Michael, G.K. (2003) The Effect of an Industrial Efluent on an Urban Stream Benthic Community: Water Quality vs. Habitat Quality. Environmental Pollution, 123, 1-13. https://doi.org/10.1016/S0269-7491(02)00363-9

[5] Patriarca, M., Menditto, A., Rossi, B., Lyon, T.D.B. and Fell, G.S. (2000) Environmental Exposure of Metals to Newborns, Infants and Young Children. Micro Chemical Journal, 67, 351-361. https://doi.org/10.1016/S0026-265X(00)00088-6

[6] Mohammad, N.A., Fazle, E. and Didar-UI-Alam, M. (2006) Risk and Water Quality Assessment over View of River Sitalakhya in Bangladesh. Academic Open Internet Journal, 19, 1-11.

[7] Zambia Environmental Management Agency (ZEMA) Act No 12 of 2011 Laws of 
Zambia.

[8] Sangodoyin, A.Y. (1991) Groundwater and Surface Water Pollution by Open Refuse Dump in Ibadan, Nigeria. Journal of Discovery and Innovations, 3, 24-31.

[9] Malik, A. and Ahmad, M. (2002) Seasonal Variation in Bacterial Flora of the Waste Water and Soil in the Vicinity of Industrial Area. Environmental Monitoring and Assessment, 7, 263-273. https://doi.org/10.1023/A:1013186218093

[10] Tetra Tech NUS Inc. (2000) Final Hazard Ranking System Package for Ely Copper Mine, Vershire, Vermont. NPL-U36-2-R-1. Prepared for USEPA, Wilmington, MA.

[11] McMenemy, J. (2001) District Fisheries Biologist for the Vermont Department of Fish and Wildlife. Personal Communication, Waterbury, VT.

[12] Masters, G.M. (1974) Introduction to Environmental Science and Technology. John Wiley \& Sons, New York, 118-119.

[13] Water Resources Management Act of 2011, Laws of Zambia.

[14] WHO (World Health Organization) (1996) Guidelines for Drinking Water Quality. Vol. 2, 2nd Ed., Health Criteria and Other Supporting Information, World Health Organization, Geneva, Switzerland.

[15] Kasonde. A. (2004) Assessment of Heavy Metals Concentrations in Kifubwa River in the View of Mining Activities. (Unpublished Thesis)

[16] Lowe, S., Dallas, H., Kennedy, M.P., Taylor, J.C., Gibbins, C., Lang, P., Sichingabula, H., Ntobolo, C., Kabangu, K., Day, J., Willems, J.A., Briggs, J.A. and Murphy, K.J. (2013) The SAFRASS Biomonitoring Scheme: General Aspects, Macrophytes (ZMTR) and Benthic Macro Invertebrates (ZISS) Protocols. SAFRASS Deliverable Report to the African, Caribbean and Pacific Group of States (ACP Group) Science and Technology Programme, Contract No. AFS/2009/219013. University of Glasgow, Glasgow, Scotland, 20 p.

[17] Lowe, S., Dallas, H., Kennedy, M.P., Taylor, J.C., Gibbins, C., Lang, P., Sichingabula, H., Ntobolo, C., Kabangu, K., Day, J., Willems, J.A., Briggs, J.A. and Murphy, K.J. (2013) SAFRASS Methodology Manual. SAFRASS Deliverable Report to the African, Caribbean and Pacific Group of States (ACP Group) Science and Technology Programme, Contract No AFS/2009/219013. University of Glasgow, Glasgow, Scotland, $36 \mathrm{p}$.

[18] APHA (American Public Health Association) (2000) Standard Methods for the Examination of Water and Waste Water. 20th Edition, APHA, Washington DC.

[19] Kunwar, R.M. and Sharma, S.P. (2004) Quantitative Analysis of Tree Species in Two Community Forests of Dolpa District, Mid-West Nepal. Himalayan Journal of Sciences, 2, 23-28.

[20] RStudio Team (2016) RStudio: Integrated Development for R. RStudio, Inc., Boston, MA. http://www.rstudio.com/

[21] Field, A. (2013) Discovering Statistics Using IBM SPSS Statistics. 4th Edition, SAGE, Los Angeles, London, New Delhi, Singapore, Washington DC.

[22] Ellery, W.N. (2004) Aquatic and Wetland Plants of Southern Africa. African Journal of Aquatic Science, 29, 283-284.

[23] Matovu, A. (2010) Impact of Wastewater Discharge and Pollution on Water Quality and Biota in Kiyanja Stream, Kawempe Division, Kampala. MSc Thesis, Makerere University, Kampala, Uganda.

[24] Janes, R.A., Eaton, J.W. and Hardwick, K. (1996) The Effects of Floating Mats of Azolla filiculoides Lam. and Lemna minuta Kunth on the Growth of Submerged 
Macrophytes. Hydrobiologia, 340, 23-26. https://doi.org/10.1007/BF00012729

[25] Salequzzaman, M., Tariqul, I.S.M., Tasnuva, A., Kashem, M.A. and Mahedi Al Masud, M. (2008) Environmental Impact of sugar Industry-A Case Study on Kushitia Sugar Mills in Bangladesh. Khulna Green World Foundation.

[26] El-Gendy, A.S., Biswas, N. and Bewtra, J.K. (2004) Growth of Water Hyacinth in Municipal Landfill Leachate with Different pH. Environmental Technology, 25, 833-840. https://doi.org/10.1080/09593330.2004.9619375

[27] Wetzel, R.G. (1983) Limnology. 2nd Edition, Saunders College Publishing, New York, 767.

[28] Nadia, M.A. (2006) Study on Effluents from Selected Sugar Mills in Pakistan: Potential Environmental Health and Economic Consequences of an Excessive Pollution Load. Sustainable Development Policy Institute, Islamabad, Pakistan.

[29] Thorne, D.W. and Peterson, H.B. (1949) Irrigated Soils, Their Fertility and Management. P. Blakiston's Son and Company, Philadelphia.

[30] Hallock, R.J. and Hallock, L.L., Eds. (1993) Detailed Study of Irrigation Drainage in and near Wildlife Management Areas, West-Central Nevada, 1987-90. Part B. Effect on Biota in Stillwater and Fernley Wildlife Management Areas and Other Nearby Wetlands. US Geological Survey, Water Resources Investigations Report 92-4024B.

[31] Ebrahim, A., Ali, M., Gautham, Jawahar, N. and Hariram, S. (2011) A Preliminary Attempt to Reduce Total Dissolved Solids in Ground Water Using Different Plant Parts. International Journal of Pharma and Bio Sciences, 2, B414-B422.

[32] Wakida, F.T. and Lerner, D.N. (2005) Non-Agricultural Sources of Groundwater Nitrate: A Review and Case Study. Water Research, 39, 3-16. https://doi.org/10.1016/j.watres.2004.07.026

[33] Rocca, C.D., Belgiorno, V. and Meric, S. (2007) Overview of In-Situ Applicable Nitrate Removal Processes. Desalination, 204, 46-62. https://doi.org/10.1016/j.desal.2006.04.023

[34] Mkandawire, M. and Dudel, E.G. (2007) Are Lemna spp. Effective Phyto-Remediation Agents? Bioremediation, Biodiversity and Bioavailability, 1, 56-71.

[35] Perry, R.H., Green, D.W. and Maloney, J.O. (2007) Perry's Chemical Engineers' Handbook. 7th Edition, McGraw-Hill, New York.

[36] Lu, Q. (2009) Evaluation of Aquatic Plants for Phytoremediation of Eutrophic Stormwaters. PhD Thesis, University of Florida, Gainesville, FL.

[37] U.S. Environmental Protection Agency, Office of Water (1986) Quality Criteria for Water (Gold Book). EPA 440/5-86-001, Washington DC.

[38] Mosley, L., Sarabjeet, S. and Aalbersberg, B. (2004) Water Quality Monitoring in Pacific Island Countries. Handbook for Water Quality Managers \& Laboratories, Public Health Officers, Water Engineers and Suppliers, Environmental Protection Agencies and All Those Organizations Involved in Water Quality Monitoring. 1st Edition, SOPAC, The University of the South Pacific, Suva, Fiji Islands, 43 p.

[39] Devlin, R.M. (1967) Plant Physiology. Reinhold, New York, 564.

[40] Chung, I.H. and Jeng, S.S. (1974) Heavy Metal Pollution of Ta-Tu River. Bulletin of the Institute of Zoology, Academy of Science, 13, 69-73.

[41] McKee, J.E. and Wolf, H.W. (1971) Water Quality Criteria. California Water Resources Control Board Publication No. 3-A.

[42] Adriano, D.C. (2001) Trace Elements in Terrestrial Environments: Biochemistry, 
Bioavailability and Risks of Metals. Springer-Verlag, New York.

[43] Wright, D.A. and Welbourn, P. (2002) Environmental Toxicology. Cambridge University Press, Cambridge, UK. https://doi.org/10.1017/CBO9780511805998

[44] Muwanga, A. and Barifaijo, E. (2006) Impact of Industrial Activities on Heavy Metal Loading and Their Physico-Chemical Effects on Wetlands of Lake Victoria Basin (Uganda). African Journal of Science and Technology, 7, 51-63.

[45] Guo, W. and Hu, Z.-H. (2012) Effects of Stolon Severing on the Expansion of Alternanthera philoxeroides from Terrestrial to Contaminated Aquatic Habitats. Plant Species Biology, 27, 46-52. https://doi.org/10.1111/j.1442-1984.2011.00335.x

[46] Mishra, V.K. and Tripathi, B.D. (2008) Concurrent Removal and Accumulation of Heavy Metals by the Three Aquatic Macrophytes. Bioresource Technology, 99, 7091-7097. https://doi.org/10.1016/j.biortech.2008.01.002

[47] Li, T.Y. and Xiong, Z.T. (2004) A Novel Response of Wild-Type Duckweed (Lemna paucicostata Hegelm.) to Heavy Metals. Environmental Toxicology, 19, 95-102. https://doi.org/10.1002/tox.20000

[48] Finlayson, B.J. and Rectenwald, H.J. (1978) Toxicity of Copper and Zinc from the Penn Mine Area on King Salmon (Oncorhynchus tshawytscha) and Steelhead Trout (Salmo gairdneri) in the Mokelumne River Basin, California. Environmental Science Branch Administrative Report No. 78, California Department of Fish and Game, Sacramento.

[49] Jain, S.K., Vasudevan, P. and Jha, N. (1990) Azolla pinnata r.br. and Lemna Minor 1. for Removal of Lead and Zinc from Polluted Water. Water Research, 24, 177-183. https://doi.org/10.1016/0043-1354(90)90100-K

[50] Mishra, V.K. and Tripathi, B.D. (2009) Accumulation of Chromium and Zinc from Aqueous Solutions Using Water Hyacinth (Eichhornia crassipes). Journal of Hazardous Materials, 164, 1059-1063. https://doi.org/10.1016/j.jhazmat.2008.09.020 